Research Paper

\title{
A study of bio-hybrid silsesquioxane/yeast: Biosorption and neuronal toxicity of lead
}

\author{
Bianca Trama-Freitas ${ }^{\mathrm{a}}$, Johnattan C.S. Freitas ${ }^{\mathrm{a}}$, Rui C. Martins ${ }^{\mathrm{b}}$, Licínio M. Gando-Ferreira ${ }^{\mathrm{b}}$, \\ Maria Emília Quinta-Ferreirac ${ }^{c}$, Rosa Maria Quinta-Ferreira ${ }^{b}$, Devaney R. do Carmo ${ }^{\mathrm{a}, *}$ \\ ${ }^{a}$ Faculdade de Engenharia de Ilha Solteira, Univ. Estadual Paulista-UNESP, Departamento de Física e Química, Av. Brasil Centro, 56 CEP 15385-000, Ilha Solteira, SP, \\ Brazil \\ ${ }^{\mathrm{b}}$ CIEPQPF- Research Center of Chemical Process Engineering and Forest Products, Department of Chemical Engineering, University of Coimbra, P-3030-790, Coimbra, \\ Portugal \\ ${ }^{\mathrm{c}}$ CNC- Center for Neuroscience and Cell Biology and Department of Physics, University of Coimbra, P-3004-516, Coimbra, Portugal
}

A R T I C L E I N F O

\section{Keywords:}

Silsesquioxane

Yeast

Lead

Biosorption

Toxicity

Neuronal toxicity

Autofluorescence

\begin{abstract}
A B S T R A C T
Lead is a heavy metal of high impact for the environment as well as for human health, being cause of several diseases. Considering the importance of obtaining an effective treatment for lead removal, a new hybrid material was developed for sorption of $\mathrm{Pb}^{2+}$ from aqueous solution. The effect of $\mathrm{pH}$, temperature, liquid/solid ratio ( $\mathrm{g} /$ $\mathrm{cm}^{3}$ ) and lead concentration on the sorption capacity of yeasts chemically modified with cubic silsesquioxane (YS) was analyzed. Additionally, the toxicity of lead on the neuronal activity was also investigated in order to assess whether the damage caused by the $\mathrm{Pb}^{2+}$ ion is reversible or not. The YS is highly promissory as sorbent of lead in high concentrations (100 and $500 \mathrm{ppm}$ ), reaching high efficiency in short contact times (15 min), and at the natural $\mathrm{pH}(4)$ of the $\mathrm{Pb}^{2+}$ solution and room temperature. The best sorption obtained was $82 \%$ removal and $248 \mathrm{mg} / \mathrm{g}$ with $500 \mathrm{~cm}^{3} / \mathrm{g}$ sorbent, $\mathrm{pH} \mathrm{4}$, room temperature and contact time of $15 \mathrm{~min}$. Besides, such high efficiencies are obtained with low quantities of biosorbent, when compared with other similar materials. The impact of lead on neuronal function was studied by measuring autofluorescence signals, associated with changes in cellular metabolism, at the hippocampal CA3 area in brain slices. In this toxicity tests, the effect of low concentrations of lead ( 1 and $3 \mu \mathrm{M})$ on neuronal activity was evaluated. After removal of the lead, the irreversibility of the observed changes can be verified, which suggests the existence of neuronal damages.
\end{abstract}

\section{Introduction}

The release of drugs and heavy metals into the environment and their effects on living organisms has been reported as one of the 40 more important conservation and management policy priorities established by scientists around the world (Fleishman et al., 2011). Some results report that these contaminants may cause diseases related to the nervous system, birth defects, and some cancer types (Birkett and Lester, 2003; Colborn et al., 2002; Birnbaum and Fenton, 2003).

Among the disruptors from inorganic origin, it was found that heavy metals do not degrade and eventually may reach living beings (Birnbaum and Fenton, 2003; Wang and Chen, 2006). Indeed, sometimes, industrial activity converts metals into chemical forms within products that can be more toxic to man. Lead $(\mathrm{Pb})$, for example, is an important metal with many industrial uses. Its widespread industrial application leads to its discard in surroundings and consequently to human exposure through food sources and the presence in drinking water (Goyer, 1990).

Vertebrates contaminated with metals such as lead, exhibit dysfunctions in the nervous system, bone marrow, kidneys, and in fetal development due to their ability to traverse the placenta (Moreira and Moreira, 2004). The use of brain slices is one way to evaluate the damage on human health, because metals like lead act directly on the central nervous system inducing acute encephalopathy or changes in behavior and cognition. Cerebrovascular damage may also occur for acute high doses (Clarkson, 1987).

Specifically, lead accumulates in the hippocampus and amygdala during animal development, reducing the dimension of the first brain structure (Audesirk, 1985). Metals, including lead, affect various preand postsynaptic functions and synaptic plasticity, having a wide range of cellular consequences (Sadiq et al., 2012). Lead, in particular, may interfere simultaneously with several ionic channels and receptor

\footnotetext{
Abbreviations: CSS, cubic silsesquioxanes; YS, yeast modified with silsesquioxane; POSS, polyhedron oligosilsesquioxane; SS, silsesquioxane

* Corresponding author.

E-mail address: devaneydocarmo@hotmail.com (D.R. do Carmo).
} 
mechanisms, with transmitter binding and uptake and in the expression of long-term plasticity. Thus, it likely interferes with autofluorescence responses implicated in mitochondrial activity, associated with neurotransmission (Kosterin et al., 2005; Shuttleworth, 2010). For these reasons, the effect of lead on neuronal autofluorescence was studied at the zinc-rich hippocampal mossy fiber synapses that are characterized by special long-term plasticity (Nicoll and Schmitz, 2005; QuintaFerreira et al., 2004). Flavoproteins autofluorescence, mainly with mitochondrial origin, was detected using visible excitation light, responding NADH to ultraviolet light (Kosterin et al., 2005; Shuttleworth, 2010).

Nanotechnology, an emerging technology, is prone to be applied in the effort to reduce costs and improve the overall effectiveness of the methods of environmental remediation (Karn et al., 2009; Zeng et al., 2017; Hu et al., 2016a), and has important biomedical applications (Kannan et al., 2005) as well. In this context, silsesquioxanes an important class of nanostructured materials has attracted huge interest in different areas of knowledge. The silsesquioxanes are compounds that have the empirical formula (RSiO 1,5) , where R can be a hydrogen or an organic group methyl, vinyl, phenyl, alkyl, alkylene, aryl, arylene or organofunctional derivatives thereof (Baney et al., 1995; Lim et al., 2012), $n$ is an even number $(n \geq 4)$ which can vary, being the resulting compound named polyhedron oligosilsesquioxane (POSS) or polysilsesquioxane when $\mathrm{n}$ is an undefined number (Voronkov and Lavrentyev, 1982; do Carmo et al., 2010). The reactivity and functionality of the compound can be changed by modifying the functional group R with a variety of organic and inorganic substituents (Baney et al., 1995; Voronkov and Lavrentyev, 1982). There are numerous applications of this compound when used as precursor in the formation of organic and inorganic hybrid compounds (do Carmo et al., 2010; do Carmo et al., 2008; Hu et al., 2016b), in catalysis (Wada et al., 2009), as additive (Bourbigot et al., 2009), polymer (Soh et al., 2007), liquid crystal (Mehl and Goodby, 1996), in electroactive films and compounds (Lucho et al., 2004; do Carmo et al., 2015; da Silveira et al., 2013), as precursor of dendrimers (do Carmo et al., 2007), in targeted delivery of therapeutic genes (Kaneshiro et al., 2007) among others.

In this work, silsesquioxane was chemically modified by adding yeast ( $S$. cerevisiae). This is a eukaryotic cell with a completely sequenced genome (Goffeau et al., 1996), that can be easily manipulated and is often applied in industrial systems that use fermentation and biosorption processes (Kapoor and Viraraghavan, 1995; Wu et al., 2012; Zhang et al., 2009a). In fact, yeasts have been extensively used for biotechnological purposes, such as bioremediation of effluents contaminated with metals and organic compounds, and for the generation of bioenergy, because of their great performance in fermentation processes (for review see (Ostergaard et al., 2000)). Also, various biomedical applications including actions on the immune system, adsorption of toxic substances, nutrient enrichment and carrier of bioactive molecules (Jenabian et al., 2010) are pointed out as relevant applications. Indeed, yeasts have great metabolic diversity, being able to use different sources of carbon and nitrogen, resist to wide changes in osmotic concentration and $\mathrm{pH}$, from alkaline to $\mathrm{pH} 2.5$, (Lujan et al., 1994; Drake and Rayson, 1996; Smith et al., 2001; Kordialik-Bogacka, 2011) and are able to grow at temperatures up to $50{ }^{\circ} \mathrm{C}$ (Abdel-Banat et al., 2010). Furthermore, the composition of the cell wall of yeasts, formed mainly by glucans, mannans, chitin, proteins and lipids (Tortora et al., 2005), has great potential to be used as biosorbents: acetamide groups of chitin, structural polysaccharides of fungi, amine groups and phosphate in nucleic acids, amine, amide, sulfhydryl, carboxylate in protein and polysaccharide hydroxyl groups are chemical groups that can sequester and pre-concentrate the metal (Volesky, 2007).

The chemical modification of yeast with the silsesquioxanes targets to increase its ability towards biosorption of metals and organic analytes with biological and environmental interest (organic disruptors). The cubic silsesquioxane has to be used in its eight vertices peripheral $-\mathrm{NH}_{2}$ groups, which are susceptible to enter in chemical reactions of nucleophilic substitution, which can occur on the surface (walls) of the yeasts. In this regard, this material intends to chemically modify the walls of yeast by exploiting the reactivity of the nanostructures presented by silsesquioxanes.

Thus, these studies aim to provide information about the potential involved in the lead biosorption process in living cells by the modified yeast. The intention is to enhance the adsorption of lead and apply it as a possible remediation of contaminated water streams.

\section{Experimental}

\subsection{Synthesis of silsesquioxane $\mathrm{Cl}\left[\mathrm{H}_{3} \mathrm{~N}\left(\mathrm{CH}_{2}\right)_{3}\right]_{8} \mathrm{Si}_{8} \mathrm{O}_{12}$}

The silsesquioxane $\mathrm{Cl}\left[\mathrm{H}_{3} \mathrm{~N}\left(\mathrm{CH}_{2}\right)_{3}\right]_{8} \mathrm{Si}_{8} \mathrm{O}_{12}$ (SS) was prepared according to the method proposed in the literature (Feher et al., 1999): $3600 \mathrm{~mL}$ of methanol, $200 \mathrm{~mL}$ of hydrochloric acid ( $\mathrm{HCl})$ and $150 \mathrm{~mL}$ of $\gamma$-aminopropyltriethoxysilane were added into a round bottom flask of $6000 \mathrm{~mL}$. The system was kept under constant stirring at room temperature for 6 weeks. The product obtained (SS) was washed using thin sintered plate funnel with cold methanol, and the product was dried at $100{ }^{\circ} \mathrm{C}$.

\subsection{Yeast modified with silsesquioxanes (YS)}

$5.0 \mathrm{~g}$ of SS are added to $100 \mathrm{~mL}$ of deionized water followed by the addition of $11.57 \mathrm{~g}$ of sodium bicarbonate $\left(\mathrm{NaHCO}_{3}\right)$ (Magossi, 2015). After a stirring period, $5 \mathrm{~g}$ of dry yeast are added and the mixture is left under rigorous stirring for further $12 \mathrm{~h}$. Then the suspension is centrifuged and the separated solid phase is washed thoroughly with deionized water. The final product will be described as YS (yeast modified with silsesquioxanes).

\subsection{Biosorbent}

Five biosorbents were applied in these tests: yeast Saccharomyces cerevisiae Type II (Sigma-Aldrich)(YST), Silsesquioxane (SS), yeast Saccharomyces cerevisiae Type II (Sigma-Aldrich) modified with Silsesquioxane (YS), dry yeast Saccharomyces cerevisiae encapsulated from a winery - ProElif ${ }^{\oplus}-(\mathrm{YW})$ and yeast Saccharomyces cerevisiae encapsulated from a winery after fermentation process - ProElif ${ }^{\oplus}$ (YWF). YW and YWF were used for comparison purposes, since these materials are used in an industrial process, especially YWF that is a waste of the alcoholic fermentation process and can thus be of low cost. Both were obtained in Adega Cooperativa de Cantanhede (CantanhedePortugal).

\subsection{Biosorption}

The sorption tests were carried out with $\mathrm{Pb}\left(\mathrm{NO}_{3}\right)_{2}$ solutions with different $\mathrm{Pb}^{2+}$ concentrations: 100,500 and $1000 \mathrm{mg} / \mathrm{L}$. The suspensions (25 mL) were shacked at $90 \mathrm{rpm}$, centrifuged (Nahita 2650) during $2 \mathrm{~min}$ at $4000 \mathrm{rpm}$ and the supernatants were collected.

The effect of the biosorbent load was assessed for several concentrations of the dry biosorbents: $50,100,250$ and $500 \mathrm{~cm}^{3} / \mathrm{g}$. The effect of $\mathrm{pH}$ on biosorption was investigated by adjusting and maintaining $\mathrm{pH}$ of the effluent at $\mathrm{pH}$ values of 4, 5, 6 and 7. For $\mathrm{pH}$ adjustment, $0.1 \mathrm{M} \mathrm{HCl}$ and $0,1 \mathrm{M} \mathrm{NaOH}$ solutions were used. The tests for evaluating the effect of temperature were performed at 25 and $40{ }^{\circ} \mathrm{C}$.

The concentration of $\mathrm{Pb}^{2+}$ in solution was measured by atomic absorption spectrophotometry (ContrAA 300 - Analytikjena) at $283.31 \mathrm{~nm}$ (Baroni et al., 2017; NIOSH, 1994).

\subsection{Toxicity of lead}

Toxicity tests were made in hippocampal slices ( $400 \mu \mathrm{m}$ thick), from female Wistar rats (12 weeks old). The slices, obtained from animals 
sacrificed by cervical dislocation, were submerged in oxygenated (95\% $\mathrm{O}_{2}, 5 \% \mathrm{CO}_{2}$ ) artificial cerebrospinal fluid (ACSF), for at least $1 \mathrm{~h}$. After this period the slices could be transferred to the recording chamber, and perfused (at $1.5 \mathrm{~mL} / \mathrm{min}$ ) with oxygenated ACSF. The recording chamber is inserted in a setup containing a fluorescence microscope (Zeiss - Axioskop) equipped with a water immersion lens (40x, N.A. $0.75,1.6 \mathrm{~mm}$ working distance). The optical signals were recorded in the hippocampal CA3 area, at the mossy fiber-CA3 pyramidal cells synaptic system, using a tungsten/halogen lamp $(12 \mathrm{~V}, 100 \mathrm{~W})$ and excitation and emission wavelengths of $480 \mathrm{~nm}$ (10 nm bandwidth) and above $500 \mathrm{~nm}$, respectively. The signals were detected using a photodiode (Hammamatsu K2G 1336). After passing through an I/V converter with a $1 \mathrm{G} \Omega$ feedback resistance, they were applied into an ACcoupled amplifier with a low $(1 \mathrm{~Hz})$ cut-off frequency and processed through a data acquisition system from National Instruments ${ }^{\mathrm{TM}}$, using the Signal Express analysis software. The points in the graphs, represented at $2 \mathrm{~min}$ intervals, are the mean of 2 consecutive data points, having each been obtained as the average of 100 sequentially recorded data. The extracellular ACSF medium had the following composition (in mM): $\mathrm{NaCl} 124.0 ; \mathrm{KCl} 3.5 ; \mathrm{NaHCO}_{3} 24.0 ; \mathrm{NaH}_{2} \mathrm{PO}_{4}$ 1.25; $\mathrm{MgCl}_{2} 2.0$; $\mathrm{CaCl}_{2} 2.0$ e D-Glucose $10.0, \mathrm{pH} 7.4,32^{\circ} \mathrm{C}$. The lead solutions were prepared from a $1 \mathrm{mM} \mathrm{PbCl} 2$ stock medium. For the tests, concentrations of 0.2 and $0.6 \mathrm{mg} / \mathrm{L} \mathrm{PbCl}_{2}$, equivalent to $1 \mu \mathrm{M}$ and $3 \mu \mathrm{M}$, respectively, were used. All experiments were carried out in accordance with the European Communities Council Directive. All efforts were made to minimize animal suffering and to use only the number of animals necessary to produce reliable scientific data.

The chemicals used were: $\mathrm{PbCl}_{2} ; \mathrm{NaCl}, \mathrm{KCl}, \mathrm{NaHCO}_{3}, \mathrm{NaH}_{2} \mathrm{PO}_{4}$, $\mathrm{CaCl}_{2}, \mathrm{MgCl}_{2}$, D-glucose (Sigma, Sintra, Portugal).

\section{Results and discussion}

\subsection{Lead biosorption}

Firstly, the material synthetized used in the sorption test was characterized by Fourier-transform infrared spectroscopy (FTIR) in order to confirm the modification of the material. The results are showed in Fig. 1.

FTIR spectrum of silsesquioxane (Fig. 1A) displays different absorption bands suggesting the complex nature of the material. Peaks identified at $3428 \mathrm{~cm}^{-1}$ and $3137 \mathrm{~cm}^{-1}$ correspond to the $\mathrm{N}-\mathrm{H}$ stretching vibration $(\nu \mathrm{N}-\mathrm{H})$. The peak observed at $2903 \mathrm{~cm}^{-1}$ is due to $\mathrm{C}-\mathrm{H}(\nu \mathrm{C}-\mathrm{H})$ deformation, while the ones identified at $1610 \mathrm{e}$ $1583 \mathrm{~cm}^{-1}$ may be assigned to the deformation $\mathrm{N}-\mathrm{H}(\delta \mathrm{N}-\mathrm{H})$. The peak at $1106 \mathrm{~cm}^{-1}$ may be assigned to symmetrical axial stretching $(\mathrm{Si}-\mathrm{O}-\mathrm{Si})(\nu \mathrm{Si}-\mathrm{O}-\mathrm{Si})$ and at $706 \mathrm{~cm}^{-1}$ corresponds to the $\mathrm{Si}-\mathrm{C}$ $(\nu \mathrm{Si}-\mathrm{C})$ stretching related to the $\mathrm{Si}-\mathrm{C}$ bond in $\mathrm{SiCH}_{2}$ (Magossi, 2015; Feher and Wyndham, 1998). Regarding the yeast spectrum (Fig. 1B), it is visible the occurrence of absorption bands between 3030 and $2800 \mathrm{~cm}^{-1}$, and 1500 and $1350 \mathrm{~cm}^{-1}$ that characteristics of the lipid acyl chains. The peaks at $1740 \mathrm{~cm}^{-1}$ and $1500 \mathrm{~cm}^{-1}$ should be attributed to the $\mathrm{C}=\mathrm{O}$ stretching of esters and $\mathrm{N}-\mathrm{H}$ deformation $(\delta \mathrm{N}-\mathrm{H})$ of peptide bonds, respectively. The band between 1250 and $1000 \mathrm{~cm}^{-1}$ is due to the contribution of phosphodiester groups of nucleic acids and phospholipids, in addition to $\mathrm{C}-\mathrm{O}$ uptake of carbohydrates (Ami et al., 2014). For the modified material (Fig. 1C), it was found that its spectrum exhibits bands identified in the previous materials. Therefore, we have the following bands: $3030-2800 \mathrm{~cm}^{-1}$ of the yeast acyl chains; $1740 \mathrm{~cm}^{-1}$ for the $\mathrm{C}=\mathrm{O}$ stretching of yeast esters; $1500 \mathrm{~cm}^{-1}$ of the $\mathrm{N}-\mathrm{H}$ deformation $(\delta \mathrm{N}-\mathrm{H})$ of the peptide bonds also of the yeast; $1106 \mathrm{~cm}^{-1}$ of symmetrical axial stretching $(\mathrm{Si}-\mathrm{O}-\mathrm{Si})(\nu \mathrm{Si}-\mathrm{O}-\mathrm{Si})$ and $706 \mathrm{~cm}^{-1}$ for the $\mathrm{Si}-\mathrm{C}(\nu \mathrm{Si}-\mathrm{C})$ stretching, both of typical of the silsesquioxane. Thus, it is possible to verify the connection between the materials, attesting the chemical modification and respective formation of the new compound.

The sorption capacity of the different materials was measured from a solution with $100 \mathrm{ppm}$ of lead initially.

The values found in the literature referred in Table 1 , where the maximum $\mathrm{Pb}^{2+}$ removal for various biosorbents materials with different initial lead concentrations, $\mathrm{pH}$ and temperature are displayed, were used as a reference to evaluate the results obtained in this study.

Our results depicted in Fig. 2 reveal that the functionalized yeast with silsesquioxane, YS, presents the maximum sorption potential with $100 \%$ of lead removal what corresponds to a sorption capacity of $102 \mathrm{mg} / \mathrm{g}$. Indeed, this new material is markedly better sorbent than YST-basic yeast - (44\% removal, $49.4 \mathrm{mg} / \mathrm{g}$ ), which is followed by dry yeast Saccharomyces cerevisiae encapsulated from winery ProElif (YW) - (37\% removal, $17.8 \mathrm{mg} / \mathrm{g})$, yeast Saccharomyces cerevisiae encapsulated from winery after fermentation process ProElif ${ }^{\circ}$ (YWF) $(25 \%$ removal, $12.6 \mathrm{mg} / \mathrm{g}$ ) and SS - octa-(3-cloropropil)silsesquioxane - (1\% removal). This test was performed with $25 \mathrm{~mL}$ of lead solution (100 ppm), $15 \mathrm{~min}$ of contact time, $25^{\circ} \mathrm{C}$ and $90 \mathrm{rpm}$ agitation.

In this context, two materials were then selected, YS and YST, for comparison. The YST was chosen because it is the base material to YS. Then, the comparison between the original and modified material is indicated. A more detailed analysis of the behavior of the modified Yeast with silsesquioxane was then further assessed by studying the effect of various parameters on its removal capacity, including the concentration of lead, $\mathrm{pH}$, temperature and sorbent concentration, aiming to reach optimal conditions for LS biosorption.

In Fig. 3, a wide range of the metal load was tested by using different initial concentrations of ion lead (100, 500 and $1000 \mathrm{ppm})$. The concentrations of $\mathrm{Pb}^{2+}$ tested in this work were based on the existence of sites with lead contamination at levels varying in the range 300-1000 ppm (Machado et al., 2013). It is important to look for high performance materials at high concentrations. As observed, the functionalized yeast, YS, removed $100 \%\left(102 \mathrm{mg} / \mathrm{g}\right.$ ) of lead, for initial $\mathrm{Pb}^{2+}$ $100 \mathrm{ppm}, 82 \%$, (248.04 mg/g) with lead $500 \mathrm{ppm}$ and decreased to $22 \%\left(70.83 \mathrm{mg} / \mathrm{g}\right.$ ) when $\mathrm{Pb}^{2+}$ was $1000 \mathrm{ppm}$. For concentrations higher than $100 \mathrm{ppm}$, the highest sorption capacity observed in Table 1 was $144 \mathrm{mg} / \mathrm{g}$ at $200 \mathrm{ppm}$ of lead, but these results were obtained with the double amount of sorbent $\left(1000 \mathrm{~cm}^{3} / \mathrm{g}\right)$. Therefore, the reference uses more sorbent for less metal sorption in comparison with this work where only $500 \mathrm{~cm}^{3} / \mathrm{g}$ of sorbent were used.

The contact time of 15 min was considered in all the equilibrium experiments based on preliminary tests where the $100 \mathrm{ppm}$ sorption of lead was maintained at $100 \%$ with YS in a time range of $5 \mathrm{~min}-2 \mathrm{~h}$ (Data not shown).

The YST sorbent just removed $27 \%(27.7 \mathrm{mg} / \mathrm{g})$, of lead in $100 \mathrm{ppm}$ solutions, $13 \%(39.8 \mathrm{mg} / \mathrm{g})$ in $500 \mathrm{ppm}$ and $0 \%$ in $1000 \mathrm{ppm}$. These results reveal that the sorption capacity increases initially, and decreased with the increase of the metal concentration to $1000 \mathrm{ppm}$, in both tests

El-Sayed (2013) showed that the sorption capacity increases with increase lead concentration but in concentration higher than $300 \mathrm{ppm}$, the sorption capacity decreases. This occurs due to the saturation of the bindings sites. In this work, the increase of sorption capacity between 100 and $500 \mathrm{ppm}$ followed by a reduction when initial $\mathrm{Pb}^{2+}$ concentration reaches $1000 \mathrm{ppm}$ shows the saturation of the materials.

Since YS removed all lead in the solution of $100 \mathrm{ppm}$, the initial $\mathrm{Pb}$ concentration that was chosen for the subsequent tests, involving the effect of $\mathrm{pH}$, temperature and sorbent concentration, was $500 \mathrm{ppm}$.

The pH influence on the sorption capacity is showed in Fig. 4, where it is observed that the ideal value for YS is $\mathrm{pH} 4$, which is the original solution $\mathrm{pH}$. In this case, the metal binding leads to a sorption capacity of $248.04 \mathrm{mg} / \mathrm{g}$ with $82 \%$ of lead removal, and the lower value is observed at pH $6(133.7 \mathrm{mg} / \mathrm{g})$ with $48 \%$ of lead removal. For YST the optimum $\mathrm{pH}$ is around 4, where the sorption capacity is of $39.8 \mathrm{mg} / \mathrm{g}$ (13\%). The literature results analyzed in Table 1 show that most of experiments are performed at $\mathrm{pH} 5 . \mathrm{pH}$ values higher than $\mathrm{pH} 6$ were not tested in our case because the $\mathrm{Pb}^{2+}$ ions precipitate above this $\mathrm{pH}$.

The $\mathrm{pH}$ values of 4,5 and 6 were tested because are reported as 


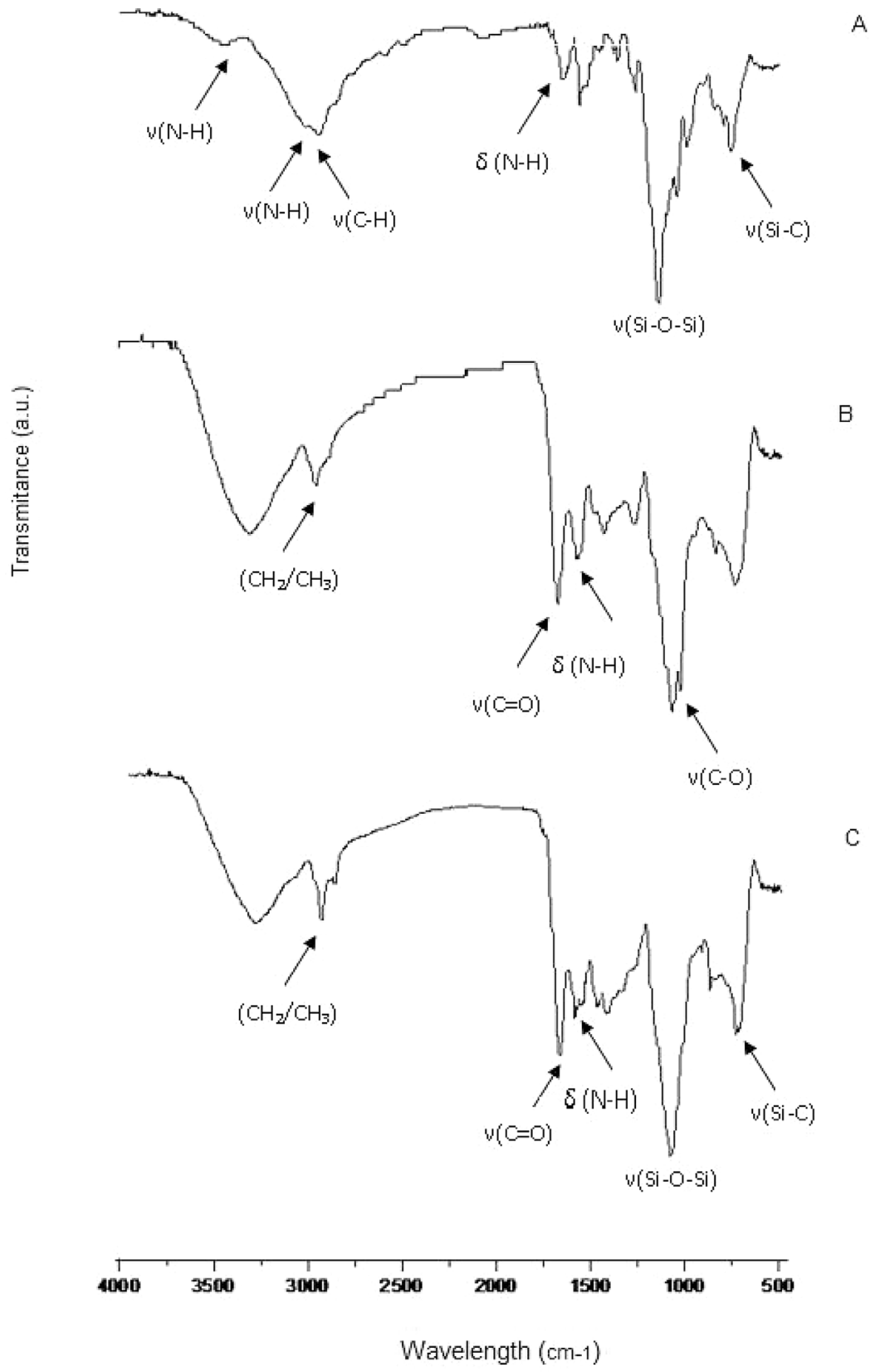

Table 1

Literature review about biosorption of lead.

\begin{tabular}{|c|c|c|c|c|c|c|c|}
\hline $\begin{array}{l}\text { Maximum metal-binding } \\
(\mathrm{mg} / \mathrm{g})\end{array}$ & Biosorbent Material & $\begin{array}{l}\text { Lead Concentration } \\
\text { (ppm) }\end{array}$ & $\mathrm{pH}$ & $\begin{array}{l}\text { Liquid-Solid ratio } \\
\left(\mathrm{cm}^{3} / \mathrm{g}\right)\end{array}$ & Temperature $\left({ }^{\circ} \mathrm{C}\right)$ & Contact Time & Reference \\
\hline 72.5 & Yeast suspension & $10-108$ & 5 & $\sim 650$ & 22 & 8 weeks & Amirnia et al. (2015) \\
\hline 160 & $\begin{array}{l}\text { Biomass from biotrickling } \\
\text { filters }\end{array}$ & 50 & 5 & 2000 & 25 & $210 \mathrm{~min}$ & Cheng et al. (2015) \\
\hline 2.34 & $\begin{array}{l}\text { Yeast from fermentor } \\
\text { brewery's }\end{array}$ & 102 & 5 & 50 & 25 & $120 \mathrm{~min}$ & Parvathi et al. (2007) \\
\hline 6.52 & Yeast from brewery & 40 & - & 312 & 25 & $>180 \mathrm{~min}$ & Zhang et al. (2009b) \\
\hline 144 & Yeast culture dried & 200 & 5 & 1000 & 25 & $1440 \mathrm{~min}$ & Özer and Özer (2003) \\
\hline 85.57 & Brewery's waste biomass & 207 & 4 & 500 & 30 & $180 \mathrm{~min}$ & $\begin{array}{l}\text { Chen and Wang } \\
\text { (2008) }\end{array}$ \\
\hline 51.81 & Brewer's yeast & 53.75 & 4 & 400 & 25 & $60 \mathrm{~min}$ & Yahiaoui et al. (2011) \\
\hline 5.74 & Waste beer yeast & 101 & 5 & 125 & 20 & $30 \mathrm{~min}$ & Han et al. (2006) \\
\hline
\end{tabular}




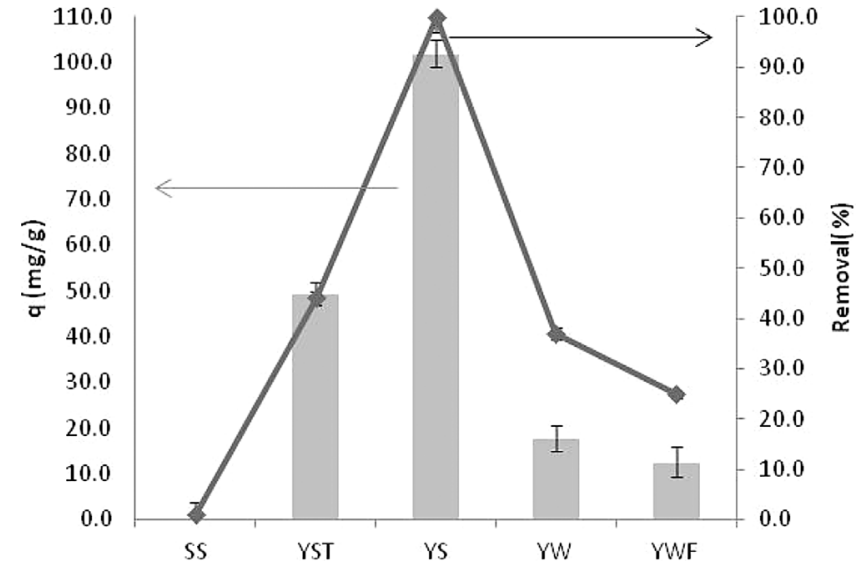

Fig. 2. Sorption capacity (q $(\mathrm{mg} / \mathrm{g})$ ) and removal percentage (\%) of lead with different materials: SS, YST (Yeast), YS (Yeast modified with SS), YW (yeast encapsulated from winery), YWF (yeast encapsulated from winery after fermentation). Initial lead solution: 100 ppm; Biosorbent: $500 \mathrm{~cm}^{3} / \mathrm{g}$; pH 4; Contact time: $15 \mathrm{~min}$.

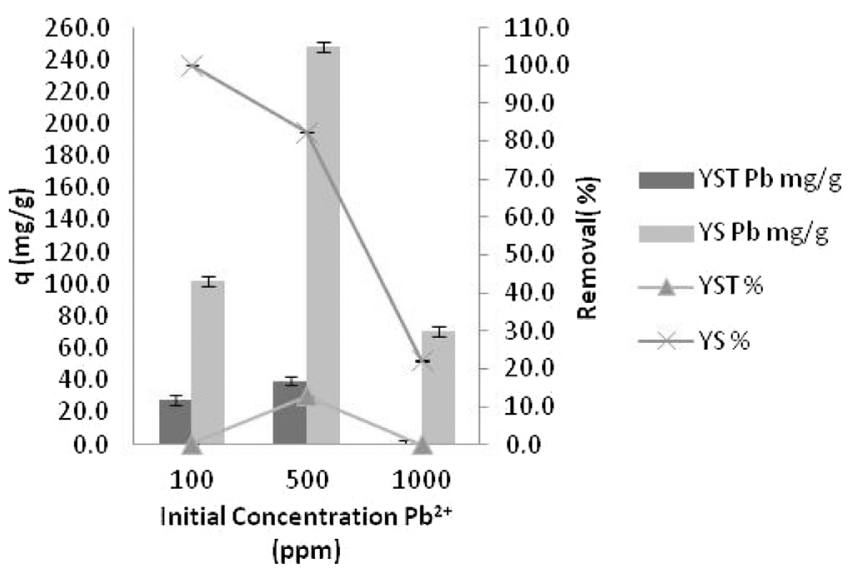

Fig. 3. Sorption of lead using different initial concentrations of $\mathrm{Pb}^{2+}$ with YST (Yeast) and YS (Yeast modified with SS). Initial Biosorbent: $500 \mathrm{~cm}^{3} / \mathrm{g}$; $\mathrm{pH} 4$; Contact time: $15 \mathrm{~min}$.

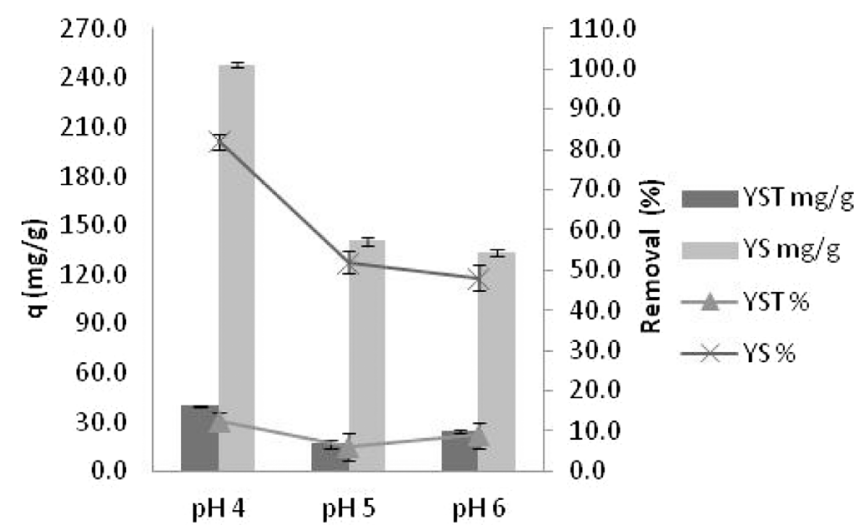

Fig. 4. Sorption of lead at different pH with YST (Yeast) and YS (Yeast modified with SS). Initial lead solution: $500 \mathrm{ppm}$; Biosorbent: $500 \mathrm{~cm}^{3} / \mathrm{g}$; Contact time: $15 \mathrm{~min}$.

favorable to biosorption of metals. Vijayaraghavan and Yun (2008) describe that $\mathrm{pH} 3$ and 6 are the most indicated to this process because of the deprotonation of carboxyl groups, where the greatest part of the metal binds by ion exchange.

The temperature effect is represented in Fig. 5. The temperature range was selected based on the work of Han et al.(2006) which shows that at temperatures higher than $25{ }^{\circ} \mathrm{C}$ the lead sorption capacity is reduced. Furthermore, the increase in temperature modifies the

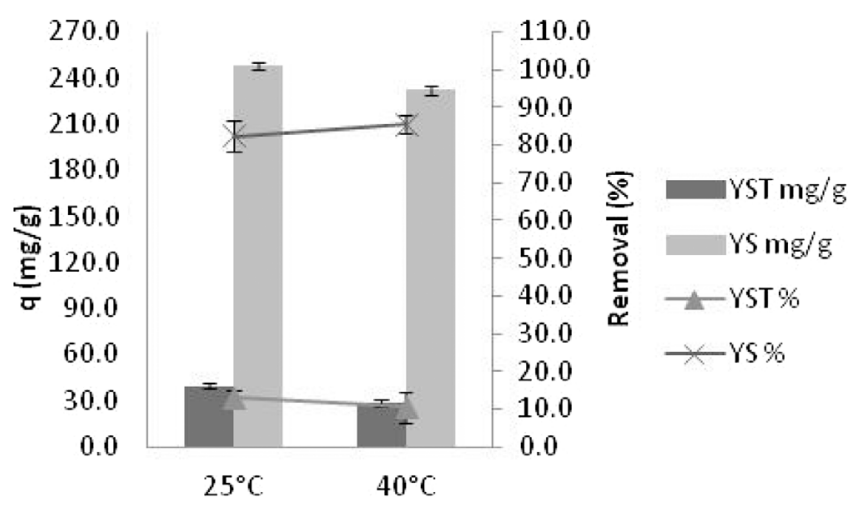

Fig. 5. Sorption of lead for different temperatures with YST (Yeast) and YS (Yeast modified with SS). Initial lead solution: 500 ppm; Biosorbent: $500 \mathrm{~cm}^{3} / \mathrm{g}$; $\mathrm{pH}$ 4; Contact time: $15 \mathrm{~min}$.

sorption sites of the yeast by changing their interactions and sorption capacity (Labuto et al., 2015). For the YS in $40^{\circ} \mathrm{C}$, the biosorption is higher than that observed at room temperature $\left(25^{\circ} \mathrm{C}\right)$, even though the difference is only $3 \%$. In YST, the temperature elevation reduced in $2 \%$ the removal percentage. Therefore, these results show that the variation of temperature does not strongly affects sorption. Thus, taking into account the cost of heating, the application of room temperature is more viable.

Assuming $500 \mathrm{ppm}$ of lead in the initial solution, $\mathrm{pH} 4$ and $25^{\circ} \mathrm{C}$, the influence of the sorbent concentration in the sorption capacity is analyzed in Fig. 6, where it is showed that the increase of the sorbent mass (decrease of the liquid/solid - L/S - ratio), increases the percentage removal and decreases the sorption capacity $(\mathrm{mg} / \mathrm{g})$ : more adsorbent, more sorption, minor metal-binding per gram of adsorbent. In the YS case, for the liquid/solid $\left(\mathrm{cm}^{3} / \mathrm{g}\right)$ ratios of 50,100 and 250 , the percentage removal of lead was $99 \%$, with $50 \mathrm{~cm}^{3} / \mathrm{g}$, and $100 \%$ with 100 and $250 \mathrm{~cm}^{3} / \mathrm{g}(27.5 \mathrm{mg} / \mathrm{g}, 56.4 \mathrm{mg} / \mathrm{g}$ and $143.2 \mathrm{mg} / \mathrm{g}$, respectively) but the best sorption capacity is with $500 \mathrm{~cm}^{3} / \mathrm{g}$, where the weight of LS was $0.05 \mathrm{~g}$ in $25 \mathrm{~mL}$ of lead solution, and the sorption capacity was $248 \mathrm{mg} / \mathrm{g}$, but lower percentage removal $-82 \%$. This occurs because, for higher $\mathrm{L} / \mathrm{S}$ values, lower mass of sorbent is applied so that the amount of lead per gram of sorbent is higher.

For the YST sorbent, the lead removal percentage was 48, 30, 27 and $13 \%$ with the liquid/solid ratios of $50,100,250$ and $500 \mathrm{~cm}^{3} / \mathrm{g}$, respectively, while regarding the sorption capacity: 13.1, 16.4, 22.4 and $39.8 \mathrm{mg} / \mathrm{g}$ were reached. These results show a similar behavior when compared with YS sorbent: the removal percentage decreases and the sorption capacity $\left(\mathrm{mg} / \mathrm{g}\right.$ ) increases by rising $\mathrm{cm}^{3} / \mathrm{g}$. In Table 1 the two

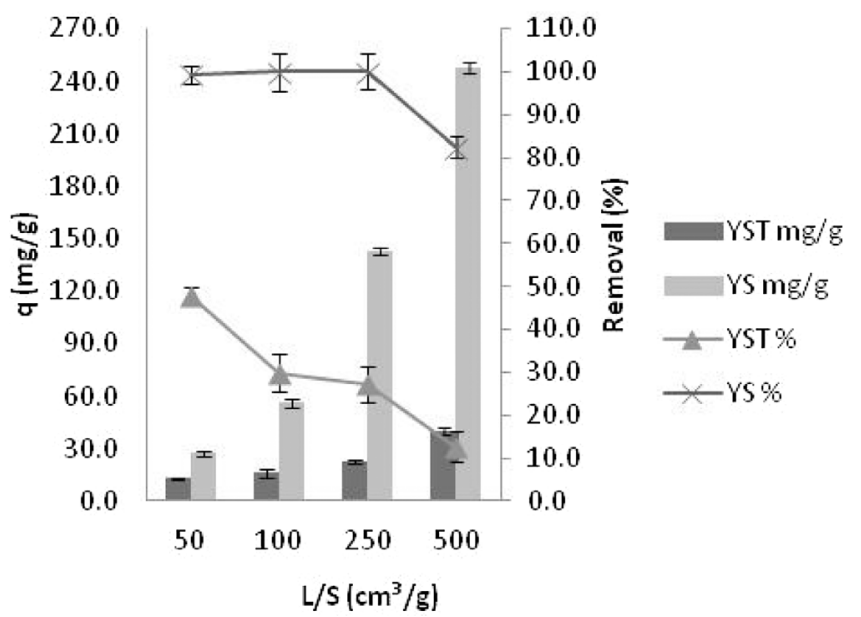

Fig. 6. Sorption of lead for different liquid/solid $\left(\mathrm{cm}^{3} / \mathrm{g}\right)$ ratios with Lev (yeast) and LS (Yeast modified with SS). Initial lead solution: 500 ppm; pH 4; Contact time: 15 min. 

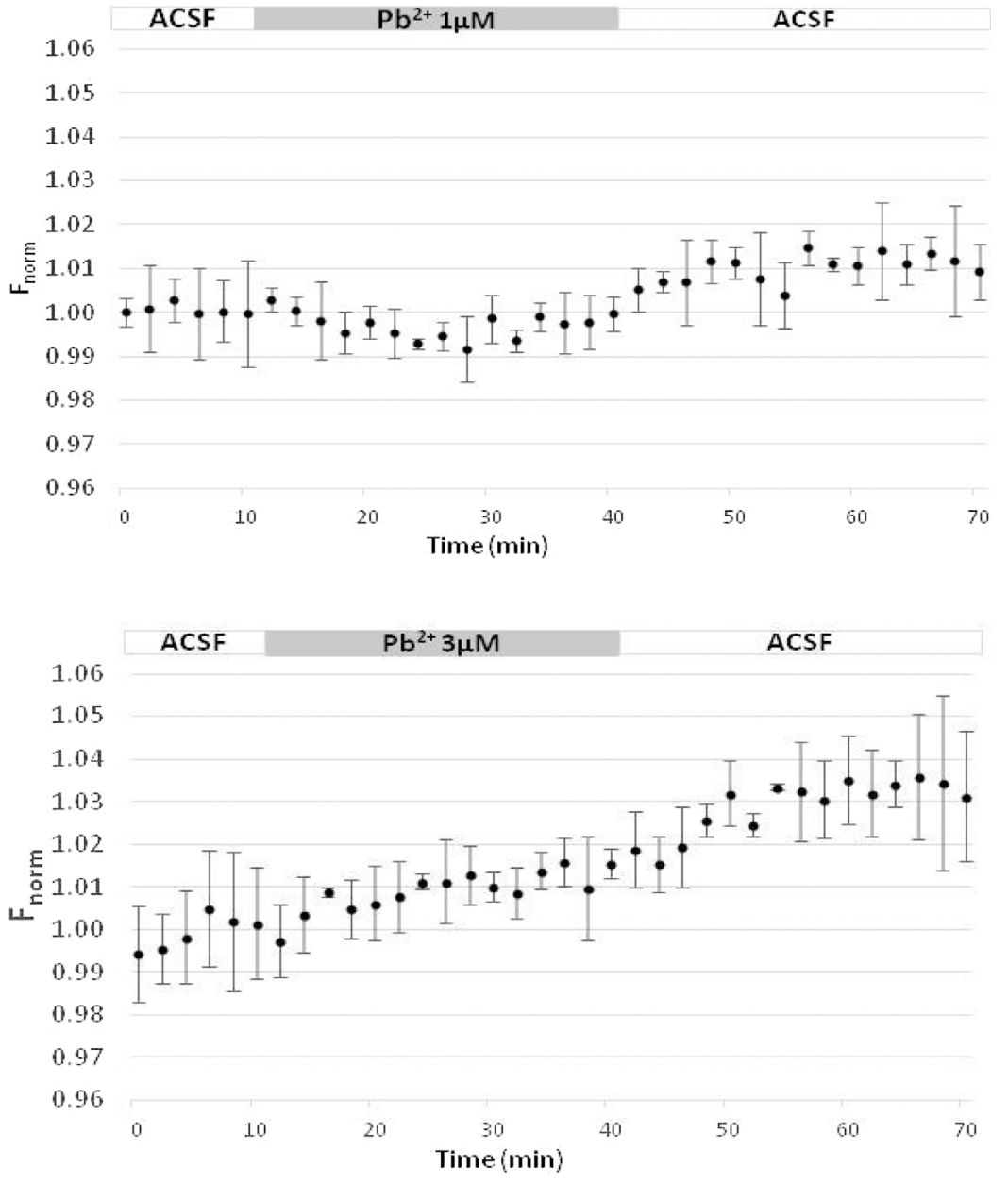

Fig. 7. Autofluorescence signals from brain slices exposed to $1 \mu \mathrm{M} \mathrm{PbCl}_{2}$. After $10 \mathrm{~min}$ in ACSF the lead solution $(1 \mu \mathrm{M})$ was applied for $30 \mathrm{~min}$, followed by an equal period in ACSF, as indicated by the bars. The data were normalized by the average of the first 10 data points. All points represent the mean \pm SEM $(\mathrm{n}=3)$.
Fig. 8. Effect of $3 \mu \mathrm{M} \mathrm{PbCl} 2$ on autofluorescence changes from brain slices. These were sequentially perfused by ACSF (10 min), $\mathrm{PbCl}_{2}(3 \mu \mathrm{M}, 30 \mathrm{~min})$ and ACSF again $(30 \mathrm{~min})$. The normalized data points represent the mean \pm SEM $(n=3)$ higher values of sorption capacity (160 and $144 \mathrm{mg} / \mathrm{g}$ ) were obtained with more than $500 \mathrm{~cm}^{3} / \mathrm{g}$ (2000 and $1000 \mathrm{~cm}^{3} / \mathrm{g}$, respectively) what shows the efficiency of yeast in metal binding with less sorbent mass.

This way, for the new bio-sorbent material, YS, the best liquid/solid ratio is $250 \mathrm{~cm}^{3} / \mathrm{g}$, where the metal binding is complete $(100 \%)$ in a solution with $500 \mathrm{ppm}$ of lead. The use of $500 \mathrm{~cm}^{3} / \mathrm{g}$ is indicated in lower lead concentrations because, in this ratio, the sorption of lead is $100 \%$.

Finally, the new synthetized material (YS) has the greatest sorption capacity of lead in comparison with the results of the literature, where the yeast dried in $200 \mathrm{ppm}$ of lead, and $1000 \mathrm{~cm}^{3} / \mathrm{g}$ (double of the load used in this work), showed the sorption capacity of $144 \mathrm{mg} / \mathrm{g}$ in 1440 min (Özer and Özer, 2003). A similar material, from biotrickling filters, has the sorption capacity of $160 \mathrm{mg} / \mathrm{g}$ using $50 \mathrm{ppm}$ with $2000 \mathrm{~cm}^{3} / \mathrm{g}$ in 210 (Cheng et al., 2015). The YS that showed fast sorption of lead $(15 \mathrm{~min})$ with reduced liquid/solid ratio $\left(500 \mathrm{~cm}^{3} / \mathrm{g}\right)$, obtained $248 \mathrm{mg} / \mathrm{g}$ of sorption capacity in $500 \mathrm{ppm}$ of lead.

The lower time used in literature of Table 1 was $30 \mathrm{~min}$ for yeast from waste beer, in $100 \mathrm{ppm}$ of lead, obtained $5.74 \mathrm{mg} / \mathrm{g}$ of sorption, approximately forty times lower than the value in this work in $15 \mathrm{~min}$ of contact (Han et al., 2006).

\subsection{Lead neurotoxicity}

The effect of lead in neuronal activity was evaluated in brain slices, at the hippocampal mossy fiber synaptic region from $\mathrm{CA} 3$ area. Autofluorescence studies, evoked by different concentrations of $\mathrm{PbCl}_{2}$ ( 1 and $3 \mu \mathrm{M})$, were performed using visible excitation light $(480 \mathrm{~nm})$ to detect flavoproteins fluorescence changes. In the presence of $1 \mu \mathrm{M}$
(0.2 ppm) $\mathrm{PbCl}_{2}$, applied for $30 \mathrm{~min}$, the autofluorescence signals had a mild transient decrease, reaching again the baseline. After washout, there was a small increase towards a steady level, that was $1.01 \pm 0.8 \%$ above baseline, in the period $60-70 \mathrm{~min}$, as shown in Fig. 7. The effect of $\mathrm{Pb}^{2+}$ is not reversible, since the signal remains potentiated upon returning to the normal extracellular medium (ACSF).

In Fig. 8 the lead concentration was $3 \mu \mathrm{M}(0.6 \mathrm{ppm})$ and the autofluorescence increased always during the lead application, being $1.01 \pm 0.7 \%(n=3)$ higher than baseline, during the interval 30-40 min. The signal continued to increase following washout reaching, in the last $10 \mathrm{~min}$, a stable value that is $1.03 \pm 2 \%$ above control.

It has been shown, in cultured hippocampal neurons, that even nanomolar concentrations of lead block the release of neurotransmitters (Braga et al., 1999). Another work, performed in the same neuronal preparation, associated lead damage with the formation of reactive oxygen species (ROS). Yin et al. (2008) found in their studies, using a much higher lead concentration $\left(20 \mu \mathrm{M} \mathrm{Pb}^{2+}\right)$, a decreased neuronal viability and an increase in ROS formation that was irreversible.

Our work confirms the irreversibility of the lead effect, being the enhancement observed upon washout likely associated with a decrease in mitochondrial activity caused by lower cellular energy requirements. An opposite autofluorescence effect, evoked by electrical stimulation, was observed in cerebellar slices (Jotty et al., 2015).

\section{Conclusions}

The new synthesized material, yeast modified with silsesquioxane, is highly promissory as sorbent of lead in high concentrations (100 and 
$500 \mathrm{ppm}$ ), reaching high efficiency in short contact times (15 min) and at the natural $\mathrm{pH}(4)$ of the $\mathrm{Pb}^{2+}$ solution and room temperature. The best sorption obtained was $82 \%$ removal and $248 \mathrm{mg} / \mathrm{g}$ with $500 \mathrm{~cm}^{3} / \mathrm{g}$

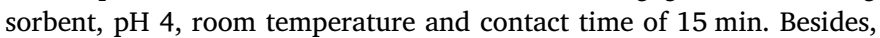
such high efficiencies are obtained with low quantities of biosorbent, when compared with other similar materials. In the neuronal studies, it was observed that low lead concentrations ( 1 and $3 \mu \mathrm{M})$ affected synaptic activity. The detected changes reveal the existence of a potentiation of the autofluorescence signals, following lead washout that may be associated with neuronal damage.

\section{Acknowledgements}

The author acknowledges the CNPq (Process 205379/2014-1) to the financial support. Rui C. Martins acknowledges the IFCT 2014 programme (IF/00215/2014) with financing from the European Social Fund and the Human Potential Operational Programme. The Biophysics Group thanks the Laboratories of Growth Factor Signaling and Brain Ischemia, Synapse Biology Group and Neuromodulation Group of CNC - Center for Neuroscience and Cell Biology, University of Coimbra, Coimbra, Portugal, for providing the rat brains. Their work was funded by strategic project UID/NEU/04539/2013.

\section{References}

Abdel-Banat, B.M.A., Hoshida, H., Ano, A., et al., 2010. High-temperature fermentation: how can processes for ethanol production at high temperatures become superior to the traditional process using mesophilic yeast? Appl. Microbiol. Biotechnol. 85, 861-867.

Ami, D., Posteri, R., Mereghetti, P., Porro, D., Doglia, S.M., Branduardi, P., 2014. Fourier transform infrared spectroscopy as a method to study lipid accumulation in oleaginous yeasts. Biotechnol. Biofuels 7, 1-14.

Amirnia, S., Ray, M.B., Margaritis, A., 2015. Heavy metals removal from aqueous solutions using Saccharomyces cerevisiae in a novel continuous bioreactor-biosorption system. Chem. Eng. J. 264, 863-872.

Audesirk, G., 1985. Effects of lead exposure on the physiology of neurons. Prog. Neurobiol. 24, 199-231.

Baney, R.H., Itoh, M., Sakakibara, A., Suzuki, T., 1995. Silsesquioxanes Chem. Rev. 95, 1409-1430.

Baroni, M.J., Barbosa, R.M., dos Santos, S.R., 2017. Análise Físico-Química De Amostras Ambientais: Determinação De Metais Por Espectrometria De Absorção Atômica Em Amostras De água E Solo. Métodos De Coleta, Amostragem E Preparo. (Acessed 17 August 2017) http://pitagoras.unicamp.br/?teleduc/cursos/diretorio/tmp/2553/ portfolio/item/26/Espectrometria\%20de\%20absorcao\%20atomica\%20\%20Mauricio\%20-\%20Rosineia\%20-\%20Samuel.pdf.

Birkett, J.W., Lester, J.N., 2003. Endocrine Disrupters in Wastewater and Sludge Treatment Processes. Lewis Publishers/IWA Publishing, London.

Birnbaum, L.S., Fenton, S.E., 2003. Cancer and developmental exposure to endocrine disruptors. Environ. Health Perspect. 111, 389-394.

Bourbigot, S., Turf, T., Bellayer, S., Duquesne, S., 2009. Polyhedral oligomeric silsesquioxane as flame retardant for thermoplastic polyurethane. Polym. Degrad. Stab. 94, 1230-1237.

Braga, M.F.M., Pereira, E.F.R., Marchioro, M., Albuquerque, E.X., 1999. Lead increases tetrodotoxin-insensitive spontaneous release of glutamate and GABA from hippocampal neurons. Brain Res. 826, 10-21.

Chen, C., Wang, J., 2008. Removal of $\mathrm{Pb} 2+, \mathrm{Ag}+\mathrm{Cs}+$ and $\mathrm{Sr} 2+$ from aqueous solution by brewery's waste biomass. J. Hazard. Mater. 151, 65-70.

Cheng, Y., Yang, C., He, H., Zeng, G., Zhao, K., Yan, Z., 2015. Biosorption of Pb(II) ions from aqueous solutions by waste biomass from biotrickling filters: kinetics, isotherms, and thermodynamics. J. Environ. Eng. 142. http://dx.doi.org/10.1061/ (ASCE)EE.1943-7870.0000956.

Clarkson, T.W., 1987. Metal toxicity in the central nervous system. Environ. Health Perspect. 75, 59-64.

Colborn, T., Dumanoski, D., Myers, J.P., 2002. O futuro roubado. L \& PM, Porto Alegre.

da Silveira, T.F.S., Silvestrini, D.R., Bicalho, U.D.O., do Carmo, D.R., 2013. Voltammetric study of a cubic silsesquioxane organically modified with imidazole and their subsequent reaction with cadmium and hexacyanoferrate(III). Int. J. Electrochem. Sci. 8, 872-886.

do Carmo, D.R., Paim, L.L., do Carmo, N.L., Stradiotto, N.R., 2007. Preparation, characterization and application of a nanostructured composite: octakis (cyanopropyldimethylsiloxy) octasilsesquioxane. Appl. Surf. Sci. 253, 3683-3689.

do Carmo, D.R., Castro, G.R., Martines, M.A.U., Dias Filho, N.L., Stradiotto, N.R., 2008 Adsorption and electropolymerization of toluidine blue on the nanostructured octakis (hydridodimethylsiloxy)octasilsesquioxane surface. Mater. Res. Bull. 43, 3286-3296.

do Carmo, D.R., Paim, L.L., Metzker, G., Dias Filho, N.L., Stradiotto, N.R., 2010. A novel nanostructured composite formed by interaction of copper octa(3-aminopropyl)octasilsesquioxane with azide ligands: preparation, characterization and a voltammetric application. Mater. Res. Bull. 45, 1263-1270. do Carmo, D.R., Silvestrini, D.R., da Silveira, T.F., Cumba, L.R., Dias Filho, N.L., Soares, L.A., 2015. Silsesquioxane organofunctionalized with 4-amino-3-hydrazino-5-mercapto-1,2,4-triazole: preparation and subsequent reaction with silver and potassium hexacyanoferrate(III) for detection of L-cysteine. Mater. Sci. Eng. C Mater. Biol. Appl. 57, 24-30.

Drake, L.R., Rayson, G.D., 1996. Plant derived materials for metal ion selective binding and pre-concentration. Anal. Chem. News Feat 1, 22-27.

El-Sayed, M.T., 2013. Removal of lead(II) by Saccharomyces cerevisiae AUMC 3875. Ann. Microbiol. 63, 1459-1470.

Feher, F., Wyndham, K.D., 1998. Amine and ester-substitued silsesquioxane: synthesis characterization and use as a core for starburst dendrimers. Chemical Communications 3. Cambridge, pp. 323-324.

Feher, F.J., Wyndham, K.D., Soulivong, D., Nguyen, F., 1999. Syntheses of highly functionalized cube-octameric polyhedral oligosilsesquioxanes (R8Si8012). J. Chem. Soc. Dalton Trans. 9, 1491-1498.

Fleishman, E., Blockstein, D.E., Hall, J.A., et al., 2011. Top 40 priorities for science to inform US conservation and management policy. BioScience 61, 290-300.

Goffeau, A., Barrell, B.G., Bussey, H., et al., 1996. Life with 6000 genes. Science 274, $546-567$.

Goyer, R.A., 1990. Lead toxicity: from overt to subclinical to subtle health effects. Environ. Health Perspect. 86, 177-181.

Han, R., Li, H., Li, Y., Zhang, J., Xiao, H., Shi, J., 2006. Biosorption of copper and lead ions by waste beer yeast. J. Hazard. Mater. B137, 1569-1576.

Hu, L., Zeng, G., Chen, G., Dong, H., et al., 2016a. Treatment of landfill leachate using immobilized Phanerochaete chrysosporium loaded with nitrogen-doped TiO2 nanoparticles. J. Hazard. Mater. 301, 106-118.

Hu, L., Zhang, C., Zeng, G., Chen, G., et al., 2016b. Metal-based quantum dots: synthesis, surface modification, transport and fate in aquatic environments and toxicity to microorganisms. RSC Adv. 6 (82), 78595-78610.

Jenabian, S.M., Pedersen, L.L., Jespersen, L., 2010. Beneficial effects of probiotic and food borne yeasts on human health. Nutrients 2, 449-473.

Jotty, K., Shuttleworth, C.W., Valenzuela, C.F., 2015. Characterization of activity-dependent changes in flavoprotein fluorescence in cerebellar slices from juvenile rats. Neurosci. Lett. 584, 17-22.

Kaneshiro, T.L., Wang, X., Lu, Z.R., 2007. Synthesis, characterization, and gene delivery of poly-L-iysine octa(3-aminopropyl)silsesquioxane dendrimers: nanoglobular drug carriers with precisely defined molecular architectures. Mol. Pharm. 4, 759-768.

Kannan, R.Y., Salacinski, H.J., Butler, P.E., Seifalian, A.M., 2005. Polyhedral oligomeric silsesquioxane nanocomposites: the next generation material for biomedical applications. Acc. Chem. Res. 38, 879-884.

Kapoor, A., Viraraghavan, T., 1995. Fungal biosorption—an alternative treatment option for heavy metal bearing wastewaters: a review. Biores.Techol. 53, 195-206.

Karn, B., Kuiken, T., Otto, M., 2009. Nanotechnology and in situ remediation: a review of the benefits and potential risks. Environ. Health Perspect. 117, 1823-1831.

Kordialik-Bogacka, E., 2011. Surface properties of yeast cells during heavy metal biosorption. Cent. Eur. J. Chem. 9, 348-351.

Kosterin, P., Kim, G.H., Muschol, M., Obaid, A.L., Salzberg, B.M., 2005. Changes in FAD and NADH fluorescence in neurosecretory terminals are triggered by calcium entry and by ADP production. J. Membr. Biol. 208, 113-124.

Labuto, G., Trama, B., Gueller, G.C.S., Guarnieri, B.S., Silva, F.V., Collazo, R., 2015. Metals uptake by live yeast and heat-modified yeast residue. Rev. Amb. Água 10. http://dx.doi.org/10.4136/ambi-agua.1577.

Lim, S.K., Hong, E.P., Song, Y.H., Choi, H.J., Chin, I., 2012. Thermodynamic interaction and mechanical characteristics of Nylon 6 and polyhedral oligomeric silsesquioxane nanohybrids. J. Mater. Sci. 47, 308-314.

Lucho, A.M.S., Pissetti, F.L., Gushikem, Y., 2004. Al2O3-coated 3-N-propylpyridinium chloride silsesquioxane polymer film: preparation and electrochemical property study of adsorbed cobalt tetrasulfophthalocyanine. J. Colloid Interface Sci. 275, 251-256.

Lujan, J.R., Darnall, D.W., Stark, P.C., et al., 1994. Metal ion binding by algae and higher plant tissues. A phenomenological study of solution $\mathrm{pH}$ dependence. Solvent Extr. Ion Exch. 12, 803-816.

Machado, S., Rabelo, T.S., Portella, R.B., Carvalho, M.D.F., Magna, G.A.M., 2013. A study of the routes of contamination by lead and cadmium in Santo Amaro, Brazil. Environ. Technol. 34, 559-571.

Magossi, M.S., 2015. Preparação E Modificação Química De Nanoestruturas De Octa (aminopropil) Silsesquioxano Para Aplicações Analíticas. (Accessed 02 January 2017) http://hdl.handle.net/11449/126543.

Mehl, G.H., Goodby, J.W., 1996. Liquid-crystalline, substituted octakis-(dimethylsiloxy) octasilsesquioxanes. oligomeric supermolecular materials with defined topology. Angw. Chem. 35, 2641-2643.

Moreira, F.R., Moreira, J.C., 2004. Os efeitos do chumbo sobre o organismo humano e seu significado para a saúde. Rev. Panam. Salud Publica 15, 119-129.

NIOSH, 1994. fourth edition. Manual of Analytical Methods (NMAM) 2. LEAD by Flame AAS: Method, Department of Health, Education, and Welfare, Publ. (NIOSH), pp. 1-7 7082.

Nicoll, R.A., Schmitz, D., 2005. Synaptic plasticity at hippocampal mossy fibre synapses. Nat. Rev. Neurosci. 6, 863-876.

Özer, A., Özer, D., 2003. Comparative study of the biosorption of Pb(II), Ni(II) and Cr(VI) ions onto S. cerevisiae: determination of biosorption heats. J. Hazard. Mater. 100, 219-229.

Ostergaard, S., Olsson, L., Nielsen, J., 2000. Metabolic engineering of Saccharomyces cerevisiae. Microbiol. Mol. Biol. Rev. 64, 34-50.

Parvathi, K., Nagendran, R., Nareshkumar, R., 2007. Lead biosorption onto waste beer yeast by-product, a means to decontaminate effluent generated from battery manufacturing industry. Electron. J. Biotechnol. 10. http://dx.doi.org/10.2225/vol10- 
issue1-fulltext-13.

Quinta-Ferreira, M.E., Matias, C., Arif, M., Dionisio, J.C., 2004. Measurement of presynaptic zinc changes in hippocampal mossy fibers. Brain Res. 1026, 1-10.

Sadiq, S., Ghazala, Z., Chowdhury, A., Büsselberg, D., 2012. Metal toxicity at the synapse: presynaptic, postsynaptic, and long-term effects. J. Toxicol. 2012, 42.

Shuttleworth, C.W., 2010. Use of NAD(P)H and flavoprotein autofluorescence transients to probe neuron and astrocyte responses to synaptic activation. Neurochem. Int. 56, 379-386.

Smith, R.W., Schneider, I.A.H., Rubio, J., 2001. Biosorption of metals onto plant biomass: exchange adsorption or surface precipitation. Int. J. Miner. Process. 62, 111-120.

Soh, M.S., Yap, A.U.J., Sellinger, A., 2007. Methacrylate and epoxy functionalized nanocomposites based on silsesquioxane cores for use in dental applications. Eur. Polym. J. 43, 315-327.

Tortora, G.J., Funke, B.R., Case, C.L., 2005. Microbiologia, 8th ed. ArtMed, Porto Alegre. Vijayaraghavan, K., Yun, Y.-S., 2008. Bacterial biosorbents and biosorption. Biotechnol. Adv. 26, 266-291.

Volesky, B., 2007. Biosorption and me. Water Res. 4017-4029.

Voronkov, M.G., Lavrentyev, V.L., 1982. Polyhedral oligosilsesquioxanes and their homo delivatives. Top. Curr. Chem. 102, 199-236.

Wada, K., Tomoyose, R., Kondo, T., Mitsudo, T., 2009. Preparation of porous ruthenium catalysts utilizing a silsesquioxane ligand; catalytic activity towards hydroformylation of 1-octene. Appl. Catal. A: Gen. 356, 72-79.

Wang, J.L., Chen, C., 2006. Biosorption of heavy metals by Saccharomyces cerevisiae: a review. Biotechnol. Adv. 24, 427-451.

Wu, Y., Wen, Y., Zhou, J., et al., 2012. The characteristics of waste Saccharomyces cerevisiae biosorption of arsenic(III). Environ. Sci. Pollut. Res. Int. 19, 3371-3379.

Yahiaoui, I., Belattaf, A., Aissani-Benissad, F., Yahia Cherif, L., 2011. Full factorial design applied to a biosorption of Lead(II) ions from aqueous solution using brewer's yeast (Saccharomyces cerevisiae). J. Chem. Eng. Data 56, 3999-4005.

Yin, S.T., et al., 2008. Effects of epigallocatechin-3-gallate on lead-induced oxidative damage. Toxicology 249, 45-54.

Zeng, G., Wan, J., Huang, D., Hu, L., et al., 2017. Precipitation, adsorption and rhizosphere effect: the mechanisms for phosphate-induced $\mathrm{Pb}$ immobilization in soils-a review. J. Hazard. Mater. 339, 354-367.

Zhang, Y., Fan, C., Meng, Q., et al., 2009a. Biosorption of Pb2+ by saccharomyces cerevisiae in staticand dynamic adsorption tests. Bull. Environ. Contam. Toxicol. 83, $708-712$.

Zhang, Y., Fan, C., Meng, Q., Diao, Z., Dong, L., Peng, X., et al., 2009b. Biosorption of $\mathrm{Pb} 2+$ by saccharomyces cerevisiae in staticand dynamic adsorption tests. Bull. Environ. Contam. Toxicol. 83, 708-712. 